Administrative and managerial issues of tax reforms

\author{
ААминистративно-управленческие проблемы \\ налоговых реформ
}

УДК 336.221

DOI 10.15826/itr.2017.3.2.032

\title{
ETYMOLOGY OF SOME TERMS IN THE TAX SPHERE: A VARIANT OF SYSTEM PERSPECTIVE
}

\author{
Evgeny N. Evstigneev \\ Peter the Great St. Petersburg Polytechnic University, Saint-Petersburg, Russia \\ Natalya G. Viktorova \\ Peter the Great St. Petersburg Polytechnic University, Saint-Petersburg, Russia
}

\begin{abstract}
The article deals with one of the permanently relevant research problems: the establishment of an integrated conceptual and categorical framework in the subject area. The purpose of the study is to propose a systemic approach to the definition of tax terms in the context of overly dynamic public systems. Research Objectives: review of Russian and foreign literary sources in subject areas (tax administration, pedagogy, IT), study of the basics of etymological analysis; a description of the system benchmark as a basis for terminology structures development; defining some taxation-related and general terms with the use of benchmarks; analysis of the results. The main methods of the study were: system analysis, a combination of historical and logical methods; synthesis. The existing definitions of the terms from different sources were formulated by the authors in the context of the genetic, homeostatic, hierarchical, target-based, functional, organizational, procedural, innovative system representations (the analysis was performed), and then authors' own interpretations were suggested (synthesis). That is, the authors propose a model for the development of specific definitions of a category, as well as its integral definition. This key provides the definitions for tax planning, tax risk, tax management, Web 2.0, and personal learning environment. Thus, the model allows the formation of different definitions based on the researcher's goal. The findings of the study showed that it is necessary to find new approaches and methods for the development of etymology of terms in the context of modern technologies. Namely, the inclusion in the conceptual apparatus of a subject-relared scientific area of such definitions such as techno-economic paradigm, technological paradigm, National Technology Initiative
\end{abstract}

\section{KEYWORDS}

Etymology, tax planning, tax risk, tax management, Web 2.0, personal learning environment, technological paradigm

\section{HIGHLIGHTS}

1. The conceptual apparatus of the subject area is influenced by technical/technological changes which are inherent in the information society

2. In today's rapidly changing overly complicated world it is important that the formation of definitions of taxation terms is performed in a systematic manner, with the use of one or another terminological structure

3. The updating of taxation terms which is going on now is due not only to the clarification of the economic and legal nature of tax terms but also to the inclusion into their contents of such aspects as personnel, information and technology 


\title{
ЭТИМОЛОГИЯ НЕКОТОРЫХ ТЕРМИНОВ В СФЕРЕ НАЛОГООБЛОЖЕНИЯ: ВАРИАНТ СИСТЕМНОГО ПОАХОАА
}

\author{
Е. Н. Евстигнеев \\ Санкт-Петербургский политехнический университет Петра Великого, \\ 2. Санкт-Петербург, Россия \\ Н. Г. Викторова \\ Санкт-Петербургский политехнический университет Петра Великого, \\ 2. Санкт-Петербург, Россия
}

\begin{abstract}
АННОТАЦИЯ
В статье рассматривается одна из неизменно актуальных научных проблем - формирование комплексного понятийно-категориального аппарата в предметной области. Цель исследования - предложить один из вариантов системного подхода к определению терминов в сфере налогообложения в условиях сверхдинамичных общественных систем. Задачи исследования: обзор российских и зарубежных литературных источников в предметных областях (управление налогообложением, педагогика, информационные технологии), изучение основ этимологического анализа; описание системного эталона, как базы формирования терминологических конструкций; определение с помощью эталона некоторых налоговых и общих терминов; анализ полученных результатов. Основными методами исследования явились системный анализ, сочетание исторического и логического методов; обобщение. Имеющиеся определения терминов из различных источников структурированы авторами в разрезе системных представлений - генетического, гомеостатического, иерархического, целевого, функционального, организационного, процедурного, инновационного (проведен их анализ), а затем предложены собственные трактовки (осуществлен синтез). Предложена модель конструирования частных определений той или иной категории, а также ее интегральной дефиниции. Даны определения «налогового планирования», «налогового риска», «налогового менеджмента», «Веб 2.0», «персональная учебная среда». Предложенная модель позволяет формировать разноплановые дефиниции с учетом того или иного целеполагания исследователя. Полученные в результате исследования выводы показали необходимость поиска новых подходов и методов к формированию этимологии терминов в контексте развития современных технологий. А именно, включению в понятийный аппарат предметной научной области таких дефиниций, как технико-экономическая парадигма, технологический уклад, национальная технологическая инициатива
\end{abstract}

\section{КЛЮЧЕВЫЕ СЛОВА}

Этимология, налоговое планирование, налоговый риск, налоговый менеджмент, Веб 2.0, персональная учебная среда, технологический уклад

\section{ОСНОВНЫЕ ПОЛОЖЕНИЯ}

1. На понятийный аппарат в предметной области влияют изменения техникотехнологического характера, присущие информационному обществу

2. В быстроменяющемся сверхсложном мире при формировании налоговых дефиниций важно подходить системно, применяя ту или иную терминологическую конструкцию

3. Актуализация налоговых терминов связана не только с уточнением экономической и правовой природы, но и включением в их содержание таких аспектов как кадры, информация, технологии 


\section{Introduction}

Terminological confusion or terminology maze is a topic for constant discussion among scientists in different academic fields. It is accepted that such a discussion is the expression of private views based on the knowledge and experience of a researcher, as well as on their inner world, in respect of a particular term. But another approach to the evolution of the terminology apparatus has become more important nowadays, and that is the need to develop a set of vocabulary structures that define not only the area of knowledge but also the external environment that plays a crucial role for any basic category. The current situation in the world means that information and telecommunication technologies are the priority areas for social development and that they fundamentally change the economic, political, moral and other foundations, the mentality of individuals, groups and society as a whole. Therefore, if we refer to the subject area of this article, i. e., taxation, the valuable outcome is not only the updating of the existing tax terms and the elaboration of new categories, but also their inclusion in the conceptual and categorical system of terminology that characterizes scientific and technological progress in the modern society.

The goal of the research is the development of a structural solution for the formation of both specific definitions in taxation sphere and definitions for related terms which together form the foundation for the understanding of the sphere of taxation in the context of digital economics development. In order to achieve this goal, we perform the following research. First of all, the existing theoretical and practical developments in respect of etymology in tax sphere are analysed. Secondly, a methodological solution developed by the authors is suggested, which is based on system approach and takes into consideration various cross-sections of taxation as a complex system. Thirdly, this solution is tested in the actualization of certain tax terms (tax planning, tax risk, tax management), as well as of such definitions which are important for any sphere, e. g.,
Web 2.0, Personal Learning Environment. Fourthly, conclusions and suggestions are issued in respect of further improvement of the special conceptual framework in the context of the advanced technological paradigm.

\section{Literature review}

It is not only the academics studying economics who examine the issues involved in tax planning, tax risk and tax management, but also practicioners. The first tend to cover tax administration issues at both macro and micro levels (for example, I. A. Mayburov, Yu. B. Ivanov, L. I. Goncharenko, V. G. Panskov, M. R. Pinskaya [1], E. S. Vylkova [2]). These studies, first of all, refer to methodological approaches of systemic nature. Practical aspects are examined in the works by A. V. Bryzgalin [3], D. N. Tikhonov and L. G. Lipnik [4], which deal only with taxpayers and their ability to legally reduce the tax burden, as well as the risks involved. The administration of taxation at the state level is reflected in the studies of F. F. Khanafeev and O. A. Mironova [1].

Foreign sources of information are mainly focused on tax planning in business. For example, a work in the sphere of accounting [5] shows the impact of the effective tax rate reflected in GAAP on the tax burden of an organization. Tax planning as part of the financial management of an economic entity is described in the study [6]. The problems of managing tax procedures through offshore financial centres are analyzed in other studies $[7 ; 8]$. The tax risks in the economic security system of an organization have been quite profoundly analyzed by Ukrainian scholars: their studies present the specificity of this type of risk and outline some approaches to tax burden estimation [9]. Tax planning issues and related risks are the subject of another research [10]. It reflects the specifics of oil industry enterprises.

C. Lavermicocca and J. Buchan showed the impact of reputation risk on tax administration in an organization [11]. And the assessment of the efficiency of tax administration was generally given by other scholars [12]. 
Due to the fact that any subject matter is related to human resources, their qualitative characteristics and now also to the progressive technologies, we will briefly outline the current state of affairs in these areas. It should be noted that we did not manage to find any studies in this area directly related to taxation. As a rule, they are linked, respectively, to pedagogics and information technology. We will describe some of them. An empirical study of the factors determining the demand for lifelong learning from the perspective of the people who would like to learn is given in the work of B. Sabrià-Bernadó., X. LlinàsAudet and S. Isus [13].

The opportunities of professional communications through the social services of Web 2.0 are shown by J. Rodríguez Terceño, J. E. Gonzálvez Vallés and D. Caldevilla Domínguez [14], S. L. Alam, J. Campbell and R. Lucas [15], and the general trajectory of the transition to artificial intelligence and, accordingly, to Web 3.0 are described by B. Piñeiro Torres and A. García González [16].

It should be noted that the above brief review of literary sources provided an opportunity for the authors to start developing some approaches for the wording of individual definitions of taxes and related nature.

\section{Research methods: etymology system analysis}

In 2004, V. N. Toporov, the renowned Soviet and Russian linguist, RAS academician, wrote: "It is difficult to say to which extent the "traditional principles" of etymology include going to non-linguistic areas... Etymology is based on a theoretical framework which, in the comparative historical linguistics as such, is currently facing fairly serious criticism or is defined in accordance with the new views ... Arguments for replacement of the old method of comparison of individual isolated elements by the comparison of the whole bundles of elements which make up a system are becoming increasingly more persuasive..." [17]. He further highlighted a weekly-structured problem of what etymology will become like in the future, and tried to outline some ways to answer this question.

He regards etymology as a combination of the analysis tools taken from phonetics, word formation, lexicology and other disciplines in order to solve the problem of the origin of the word, and the combination of these tools does not remain the same in different cases. However, attempts to take into consideration the elements of structural approach result in the determination of the coordinates of different systems (phonological, derivative, lexical, etc.). The intersection of these coordinates creates a word or word formation and defines their subsequent development.

Can etymology be structural, and can it use structural analysis techniques? In his answer to this question, V. N. Toporov shows that structural linguistics continues its expansion to numerous new areas which are very far from its origins [17]. This is why a scholar of etymology must decide on the exact area of the research, determining the configuration of the problems in accordance with the requirements of structural linguistics, as well as the techniques of analysis that should be used. Three findings, important for modern scholars, follow this point:

- structural approach to etymology is fundamentally acceptable, and the reason for its application is that each new word arises at the intersection of a number of systems, as a clot in a particular language field ${ }^{1}$;

- the traditional understanding of the tasks of etymology still disregards, almost completely, the systemic approach to the facts of the language;

${ }^{1}$ The rationale for the structural approach to etymology lies in the fact that a new word arises at the intersection of a number of systems, being something a sort of a hub in a particular language field. Based on one word (phrase), it is difficult to come to a conclusion about the systems that gave rise to that word; it is easier to analyze that if several related words are available. Therefore, in the future, etymology should increasingly focus not on isolated words, but on the arguments that pertain to different systems: semantic, wordformative, lexical, etc. The extent of the structural development of the etymology statements will depend on the progress of the structural methods in each of these areas. 
- if etymology at least indirectly deals with facts that reflect systemic relationships, then formalization and the use of precise methods are possible, including for the solution of challenging tasks of simulating real-life phenomena or processes ${ }^{2}$.

With the use of these approaches in the area of taxation, it is practical to present the etymology of terms from systemic positions ${ }^{3}$. It is therefore proposed to examine structural etymological developments as a complex system. Given the characteristics of the overall tax process, it is possible to display such a system in the form of a verbal model $(M)$ which outlines the general conceptual framework of taxation:

$$
\begin{gathered}
M=\{V S\},[\{S P\},\{O P\}]=\{a f, a s, a \mathrm{e}, a p\}, \\
{[\{p g, p y, p s, p d, p f, p o, p p, p n\},\{O P\}],}
\end{gathered}
$$

where $V S$ - External environment and its aspects (ai); $S P$ - semantic part and its system presentation (pi); OP - supporting part (subsystems, scientific and practical tools).

The system is studied in retrospect and in the dynamics, is open, reflexive and polyhierarchic.

The external impact of the system requires the development of a business strategy (doctrine) aimed at adapting to the external environment, and such adaptation is needed to maintain the system's sustainable development within a specified period of time. There are four universally-meaningful aspects characterizing the external environment: philosophical $(a f)$, social-political (as), economic (ae), legal (ap). The level of their understanding determines the building of the semantic part of the model, i. e., its systemic concepts. We will give only a brief description of them, because a detailed description is present in the research [18].

Genetic $(p g)$ : formation of fundamental attitudes, judgments and terms ac-

\footnotetext{
2 The essence of such models is based on indicating which questions should be answered in order to consider the etymology data on a word necessary and sufficient.

${ }^{3}$ For the purposes of this article, the term "etymology" refers to the method of research used in identifying the history of the origin of words or phrases and the result of such identification.
}

cepted and shared by the scientific community in the taxation area (paradigm). Target-based $(p d)$ : goal-setting, development of a doctrine which is primarily aimed at adaptation to the conditions of the external environment. Homeostatic (py) - maintenance of the dynamic equilibrium and sustainability of the tax system. Hierarchical ( $p s)$ - structuring of the tax administration system from different points of view. Functional $(p f)-$ a set of features (functions) performed by the participants of the tax relationship. Organizational $(p o)$ - pooling of resources in order to implement target installations. Procedural $(p p)$ - algorithmization, modelling of actions and procedures in accordance with the law. Innovation (pn): the use of innovations, generation of new ideas, attitudes and approaches in today's environment. The sequence of theoretical thinking on a complex system is approximately as follows: paradigm - doctrine (goals) homeostasis - functions - resources algorithms - innovation - paradigm. The first presentation forms the current paradigm, the next six ones reveal the system's functioning, and the last one closes the whole chain, providing the transition to the new paradigm.

The existing theoretic developments in taxation and related fields, scientific and practical techniques and methods, modern technology and web services all shape the model in the form of subsystems and scientific and practical instruments. The supporting part $(O P)$ can be presented as follows:

$$
\begin{gathered}
O P=\{O P 1, O P 2, O P 3\}= \\
=\{o b, k o\},\{n o, i o, m o, t o\},\{s i, p i\},
\end{gathered}
$$

where OP1 - support within genetic representation; $O P 2$ - support for the functioning of the system; OP3 - support in the framework of innovation; $o b$ - educational resources; $k o$ - personnel support; no - legal and regulatory support; io information support; mo - technical support; to - technology support; si - scientific theories, methods and techniques of research; $p i$ - practical tools.

Thus, the proposed structural etymological structure, as a complex system, 
makes it possible, through analysis and synthesis techniques, to interpret a definition, propose new structures depending on the objective to be achieved, integrate specific definitions into generic ones, and take into account the importance of some systemic perceptions. The universal nature of this method makes it possible to use it for the formation of a conceptual apparatus to be used for a professional area or in legislative activity. In essence, it is a model for etymological analysis, a system sample (benchmark) for the modelling tax objects and systems.

However, there are currently two interrelated cognitive crises - the crisis of social sciences/economic science and the management crisis [19]. They are related to the description (theory) without solutions and to the availability of recommendations without descriptions (theories). The inconsistencies of the quantitative methods and the quality of the decisions taken lead to a cognitive gap. The situation becomes even more difficult when we are dealing with overly complicated and extremely fast systems. The economic reality is so various and dynamic that the research of this area does not keep up with its development. Therefore, in the future this model requires revision and continuous refinement.

\section{Applied etymology-related aspects in the sphere of taxation}

Etymological study of some terms have been performed by the authors of the article by the traditional methods for simple systems and/or based on the proposed system pattern for complex and overly complex systems ${ }^{4}$. The first group includes the term "tax planning", while the second includes tax risk, tax administration (tax management), Web 2.0 and personal learning environment.

${ }^{4}$ A complex system is a system consisting of many interacting representations (subsystems), and due to this fact it acquires new properties that are not present at the subsystem level and cannot be reduced to the properties of one representation. An overly complicated system is a system fully open to technological, economic, social, institutional and other innovations aimed at ensuring its sustainable equilibrium and development in an overly complicated and constantly changing world.
The following are only some general approaches and final results of etymology studies. The method used to conduct each of the studies is presented, in sufficient detail, in the works of the authors [18; 20-22].

The term "Tax Planning (TP)". The TP system is defined as simple and uses epy methods and models of classical and neoclassical theories. The etymological study of the system is based on the traditional approach: identification and analysis of various definitions of the concept under consideration, the generalization of these definitions, the author's vision of private interpretations of the term $\mathrm{TP}$, the synthesis of private interpretations and, on its basis, obtaining of the author's result for the phrase Tax Planning (within the specified scientific theories).

Six of the most distinctive approaches to the definition of "tax planning" have been identified. The following are the results of interpretations of tax planning based on the authors' understanding.

1. Tax planning is the activity of an economic entity aimed at increasing profits and cash flow.

2. Tax planning at the level of an economic entity is a part of the management of its financial and economic activities within its general strategy.

3. Tax planning is a legitimate way to avoid paying taxes based on the use of statutory benefits and the methods of tax liabilities reduction.

4. Tax planning means active and informed taxpayer actions aimed at reducing tax payments (contributions), with due account for any risks and negative consequences.

5. Tax planning means taxpayer's active efforts to optimize taxation, taking into account the possible risks and negative consequences.

6. Tax planning is part of the managerial activity of the economic entity as part of its economic development strategy and tactics.

To sum up the above and integrate the generally accepted explanations, the following definition was originally proposed: "Tax planning provides legitimate means of optimizing the taxation of an 
economic subject, taking into account the strategy and tactics of its economic development". The definition was further modernized to take into account the technological peculiarities of modern society and has taken the following form:

"Tax planning is the legitimate means of optimizing the taxation of an economic entity with due account for the strategy and tactics of its economic development, with the use of traditional methods and techniques, as well as modern technologies, specialized Internet resources and Web services".

The term "tax risk (TR)". The TR system is defined as complex. Its etymological study was performed with the use of the traditional approach combined with the proposed system pattern. The algorithm here is as follows: first, an analysis is made of the existing interpretations of the term under review from the point of view of systemic presentation. Such approaches are then synthesized into new specific definitions, and if no systemic representation is reflected in the existing definitions, the author's insignt into the matter is outlined. In conclusion, the authors synthesize the specific definitions into a generic definition which takes into account the relevant systemic representations. In other words, the logic of the work is as follows: first, definitions are synthesized horizontally within each system view (specific, narrow-sense definitions are generated) and then, vertically, based on the results of the previous iteration, an integral broad-sense definition is outlined.

The analysis is summarized in Table 1. As a result of the analysis and synthesis of separate definitions of tax risk, an integral definition is presented: "Tax risk is an indicator of the probability of negative effects? and it is necessary in tax administration for the assessment of the sustainability and equilibrium of its polyhierarchic structure".

It was on the basis of this algorithm that the authors approached the interpretation of the definition of tax management, as well as the terms "Web 2.0" and "personal learning environment". The results of such studies are shown below.
The term "tax administration (tax management, TM)". The authors agree with the arguments supporting the identity of the terms "tax administration" and "tax management" in the work [2] and suggest to define them from the standpoint of complex systems. In terms of theory, this has made it possible to focus on different issues: the identification of isomorphism in various fields of scientific knowledge, the possibility of shifting the conceptual framework of management from one area (industry) to another; a study of the mechanism for adapting staff to various factors in the external environment; identification of the emergent effects associated with overlapping systems of different types.

Based on the proposed system approach, as in the case of "tax risk" determination, the generally accepted terminology structures in tax matters are related to one or another systemic view. Now we will describe the specific definitions that we collected.

1. Genetic representation. The synthesis of definitions from literature and the authors' vision of the issue suggest the following definition: "Tax administration (tax management) is the process of preparing and making decisions in an open system that regulates the interaction of the participants in a tax relationship, their interests aimed at various goals, in generating the income portion of the budget".

2. Homeostatic representation. The following definition is suggested here: "Tax administration (tax management) is prediction of innovation, development and implementation of management actions aimed at maintaining the dynamic equilibrium and sustainability of the open system in accordance with the selected state tax policy".

3. Hierarchical representation. Based on the synthesis of the existing definitions, the following definition can be suggested: "Tax administration (tax management) is the activities of entities of a polyhierarchic structure in a non-reflexive system for the implementation of the state tax policy at the macro level and, in accordance with the goals and objectives set, at the level of economic entities". 
Tax risk as a differentiated whole: definitions

Table 1

\begin{tabular}{|c|c|c|}
\hline Representation & \begin{tabular}{|c|}
$\begin{array}{c}\text { Analysis of the available definitions } \\
\text { formulated by scholars }\end{array}$ \\
\end{tabular} & Author-suggested definition \\
\hline Genetic & $\begin{array}{l}\text { Tax risk is: } \\
\text { 1. Probability (possibility) of finan- } \\
\text { cial loss (D. N. Tikhonov [4], } \\
\text { V. G. Panskov [1]). } \\
\text { 2. The risk of unforeseen alienation of } \\
\text { funds (A. G. Ivanyan [23]). } \\
\text { 3. Possible occurrence of adverse } \\
\text { (mainly financial) and other conse- } \\
\text { quences (L. I. Goncharenko [1]) }\end{array}$ & $\begin{array}{l}\text { Tax risk is the probability of adverse } \\
\text { financial, as well as non-financial, con- } \\
\text { sequences for all the participants of tax } \\
\text { relations }\end{array}$ \\
\hline Homeostatic & $\begin{array}{l}\text { Tax risks emerge due to the following } \\
\text { factors: } \\
\text { 1. Changes in tax policy, tax rates } \\
\text { (E. V. Berezhnaya [24]). } \\
\text { 2. Irrational actions by an official } \\
\text { (persons) (N. A. Pavlenko [25]). } \\
\text { 3. Actions (failure to act) of state } \\
\text { authorities (local governments) } \\
\text { (A. G. Ivanyan [23]). } \\
\text { 4. Actions (failure to act) of partici- } \\
\text { pants in tax relations (L. I. Goncha- } \\
\text { renko [1]). } \\
\text { 5. Disagreements between taxpayers } \\
\text { and tax authorities; use of tax minimi- } \\
\text { zation methods by taxpayers } \\
\text { (M. R. Pinskaya [1]) }\end{array}$ & $\begin{array}{l}\text { Tax risk is an integral indicator of the } \\
\text { impact of endogenous and exogenous } \\
\text { factors for the performance of opera- } \\
\text { tions required to increase the stability } \\
\text { and equilibrium of the tax management } \\
\text { system }\end{array}$ \\
\hline Hierarchical & $\begin{array}{l}\text { Subjects of tax risks: } \\
\text { 1. Taxpayers (D. N. Tikhonov [4], } \\
\text { A. G. Ivanyan [23]). } \\
\text { 2. Officials or groups of persons } \\
\text { responsible for tax liabilities in a } \\
\text { particular organization } \\
\text { (N. A. Pavlenko [25]). } \\
\text { 3. Taxpayers and the state } \\
\text { (V. G. Panskov [1]) }\end{array}$ & $\begin{array}{l}\text { Tax risk is the uncertainty of the taxable } \\
\text { entity that arises in the process of tax } \\
\text { and taxation administration at the mac- } \\
\text { ro and micro levels, as well as in terms } \\
\text { of territorial and sectoral specificity }\end{array}$ \\
\hline Target-based & $\begin{array}{l}\text { The purpose of tax risk assessment is } \\
\text { to determine the potential for adverse } \\
\text { effects (N. A. Pavlenko [25]) }\end{array}$ & $\begin{array}{l}\text { Tax risk is a qualitative assessment at } \\
\text { different levels of the negative tax ef- } \\
\text { fects hierarchy }\end{array}$ \\
\hline Functional & $\begin{array}{l}\text { Tax risks arise in the area of tax plan- } \\
\text { ning at the level of economic entities } \\
\text { (E. N. Evstigneev [26]) }\end{array}$ & $\begin{array}{l}\text { The tax risk is the possibility of ad- } \\
\text { verse outcome when the subject of tax } \\
\text { relations is involved in the forecasting, } \\
\text { planning, regulation and control func- } \\
\text { tions }\end{array}$ \\
\hline Organizational & No definitions & $\begin{array}{l}\text { Tax risk is combining different types } \\
\text { of tax risks in accordance with their } \\
\text { classification in order to calculate the } \\
\text { integral risk indicator }\end{array}$ \\
\hline Procedural & $\begin{array}{l}\text { The procedures that result in tax risks: } \\
\text { 1. Tax payment and optimization } \\
\text { (D. N. Tikhonov [4]), } \\
\text { 2. Tax audit (M. R. Pinskaya [1]) }\end{array}$ & $\begin{array}{l}\text { Tax risk is the measurement of the prob- } \\
\text { ability of various adverse effects that } \\
\text { arise in the process of tax assessment } \\
\text { and administration }\end{array}$ \\
\hline Innovative & No definitions & $\begin{array}{l}\text { Tax risk is an integral measure of the } \\
\text { probability of negative tax effects which } \\
\text { is calculated with the use of modern } \\
\text { methods, tools and technologies to } \\
\text { develop a tax management model }\end{array}$ \\
\hline
\end{tabular}


4. Target-based representation. In this systemic context the definition under consideration is interpreted as follows: "Tax administration (tax management) is the process of developing, in a dynamic system, of state tax policies, the doctrines of economic agents relating to the goal-setting, plans for the achievement of those goals and the evaluation of development trajectories".

5. Functional representation. Within the context of this representation, the following definition is proposed: "Tax administration (tax management) is the implementation, in a non-reflexive system, by the participants of fiscal relationship of their functional assignments in order to achieve the targets of the state tax policy and the objectives of the economic agents".

6. Organizational representation. In terms of cybernetics, this is the distribution of tasks, resources and decisionmaking power in a polyhierarchic structure of tax administration. Therefore, the organizational representation is closely related to hierarchical, target-oriented and functional, so it has to be considered with due account for the dynamic properties of the system. With this in mind, we suggest the following definition: "Tax administration (tax management) is the allocation of tasks, resources and decision-making authority by the subjects of tax relationships in the sections of the polyhierarchic structure of the system, taking into account its dynamic properties".

7. Procedural representation. In terms of the procedural representation of the system, the following definition is proposed, based on the summary of the specific interpretations of TM: "Tax administration (tax management) is the competent application of legal procedures and administrative regulations, the use of modern technologies, economic and mathematical methods and models for the management of tax issues".

8. Innovative representation. It completes a consistent chain of research into the complex system and provides a basis for the formation of the paradigm on a particular section of the timeline. This is where the authors' view on the problem arises from: "Tax administration (tax management) is the process of preparation and making of decisions based on the use of all kinds of tax innovations and advances in science and technology through a combination of formal and informal thinking, as well as simulations".

In the broadest sense, the following integral definition was formulated: "Tax administration (tax management) is the decision-making process in an open, dynamic, non-reflexive tax system aimed at achieving the goals and objectives, harmonizing and regulating the interaction between the participants of tax relations".

The term "Web 2.0". Web 2.0 system is initially defined as complex (as well as the subsequent system referred to as "Personal Learning Environment"). But in the course of the model study they had to be treated differently, as overly complicated systems.

There are four main paradigms of economic science: 1) Neoclassical, as the basis for the management of simple systems; 2) Institutional one, the distinctive feature of which is that not only economic, but also non-economic factors of socio-economic development are considered (such as rules, traditions, norms); 3) Evolutionary, which, unlike the first two, is based on a dynamic understanding of the structure of the socio-economic environment; 4) The newly emerging systemic one ${ }^{5}$.

According to G. B. Kleiner, "the last stage before the new development of economic theory can be a systemic paradigm that sees the economy as a harmonious combination of all four types of systems" [27]. Thus, it is reasonable to highlight a specific type of systems in this overly

${ }^{5}$ In the emerging paradigm, systemic in nature, socio-economic space (including its dynamic dimension) is seen as a combination of economic systems that include both agents and institutions, as well as genetic mechanisms for the reproduction of agency populations. In this way, multidimensional consideration is given to the clusters that have the characteristics of technological, economic, social, institutional and other systems. Socio-economic systems become the main object of research, and the scope of research is their development based on the interaction of the internal subsystems and the influence of the external environment. 
complicated ever-changing world, with a matching nature: open, overly dynamic, non-reflexive. The key object of research here is on socio-economic systems, and the scope of research is the development of these systems based on the effects of the external environment and on the interaction of internal subsystems.

Today, the analysis of complexity is emerging in economic science and practice, because without such an approach it is becoming difficult to explain various phenomena and processes. The potential of the world wide web is enormous, and still it has not yet been sufficiently explored. The phenomenon of social networks is often described as a platform to support networking, while due attention is not given to the prospects and potential of the use of second and the future generations of Internet technologies for the activities of researchers and taxation practitioners.

To this end, the authors attempted to answer what Web 2.0 is based on the proposed variant of system approach. An analysis of the existing judgments and terms relating to Web 2.0 is discussed in detail in the work [22]. The data in Table 2 illustrate the end result of the etymological modelling of specific definitions.

In a broader sense, the etymology of the term in question is based on the subsequent synthesis of specific definitions which out-

Web 2.0 as a complex system: definitions

Table 2

\begin{tabular}{|c|c|}
\hline $\begin{array}{c}\text { Systemic view } \\
\text { (systemic context) }\end{array}$ & Author's vision of the problem \\
\hline Genetic & $\begin{array}{l}\text { Web } 2.0 \text { is the second generation of organization, implementation, and sup- } \\
\text { port of network resources; this is a differentiated whole, a complex (open, } \\
\text { overly dynamic, non-reflexive) system consisting of interconnected and inter- } \\
\text { related system representations and supporting subsystems }\end{array}$ \\
\hline Homeostatic & $\begin{array}{l}\text { Web } 2.0 \text { is a collection of rules and practices for maintaining homeostasis of a } \\
\text { system open to the external environment; Internet services support a sponta- } \\
\text { neous path of community development because they are created by grass- } \\
\text { root efforts of many independent members and network users }\end{array}$ \\
\hline Hierarchical & $\begin{array}{l}\text { Web } 2.0 \text { is a polyhierarchic structure of a complex system: a technology } \\
\text { platform supporting protocols, languages, standards, projects, services, and } \\
\text { applications; a platform for social interaction that is oriented towards people, } \\
\text { their knowledge and experience; a learning platform; other invariant cross- } \\
\text { sections of the non-reflexive system }\end{array}$ \\
\hline Target-based & $\begin{array}{l}\text { Web } 2.0 \text { is the foundation where a new smart society can be built, the society } \\
\text { in which the use of Internet tools and capabilities leads to qualitative changes, } \\
\text { allowing for innovative systemic effects in the research, social, economic, } \\
\text { managerial and educational spheres }\end{array}$ \\
\hline Functional & $\begin{array}{l}\text { Web } 2.0 \text { is a process of collective creativity performed by professionals, simple } \\
\text { participants and network users; this is blogging, network resources sharing, } \\
\text { production of collective publications, exchange and collaboration with data, } \\
\text { syndicating content, creation of new and effective services and applications }\end{array}$ \\
\hline Organizational & $\begin{array}{l}\text { Web } 2.0 \text { is the integration of second-generation Internet projects, applications, } \\
\text { networks, and services for breakthrough effects in research, management } \\
\text { and education; this is an ever-growing arsenal of applications, software and } \\
\text { hybrid services }\end{array}$ \\
\hline Procedural & $\begin{array}{l}\text { Web } 2.0 \text { is the system software and technology support (protocols, languages, } \\
\text { standards, procedures, blogs, programs, methods, and models), networks, and } \\
\text { Internet services that are actively developed and improved by both profes- } \\
\text { sionals and users of the network in order to create common content, develop a } \\
\text { personal learning environment and/or professional web space }\end{array}$ \\
\hline Innovative & $\begin{array}{l}\text { Web } 2.0 \text { involves integration of innovations from other system views, the } \\
\text { trajectory of development and the formation of a new smart society; It is the } \\
\text { perception and use of the Internet as a means of social communication and } \\
\text { collective intelligence, a new understanding of interactivity, an innovative } \\
\text { approach to education; this is the ever-increasing potential of smart technol- } \\
\text { ogy as the basis for building a new paradigm, web } 3.0\end{array}$ \\
\hline
\end{tabular}


line the key points characterizing the Internet of the second generation. It is the interaction with the external environment and the networking that makes it possible to place everything new and advanced on the technology platform; consistency with the ongoing changes of the complex and dynamic world to maintain a spontaneous path of development; consideration of the human factor as one of the main functions of social facilities and systems.

In a broad sense, Web 2.0 is described as an overly complicated system: completely open, overly dynamic, non-reflexive. The perspectives and potential of Web 2.0 can be disclosed and understood if we considering this phenomenon in the context of the development of the global technology. This approach provides innovative economic, managerial and research effects in any area of knowledge, including tax matters.

The term "Personal Learning Environment (PLE)". One of the main problems of the present day is education, training and retraining of staff in the context of overly complicated and constantly changing world, avalanche-like development of science and technology that characterize one or another technological paradigm [28-30]. The economically developed countries are believed to have already completed five paradigms and are now in the process of developing the sixth one. Russia can become one of such countries if it makes a quantum leap and moves to completely new technologies of a progressive nature, including in the educational environment. The logic of transformations here is more or less as follows:

- from Web 1.0 to Web 2.0 \& Web 3.0;

- from cloud and mobile technologies

to Big Data, Open Data, Block Chain;

- from closed educational courses to massive open online courses (MOOC);

- from discontinuous education to life long learning;

- from traditional education to Smart

Education;

- from group learning to the development of personal learning environments (PLE).

\begin{tabular}{|c|c|}
\hline Evolution & $\begin{array}{l}\text { PLE is a system of cognitive activities of a person in the context of modernization of } \\
\text { education and technological advances, which the person creates themselves and which } \\
\text { evolves along with their personal and professional growth }\end{array}$ \\
\hline $\begin{array}{l}\text { Definition } \\
\text { of objectives }\end{array}$ & $\begin{array}{l}\text { PLE as the primary tool for implementing lifelong learning, developing knowledge, } \\
\text { skills and competencies to address personal and professional tasks }\end{array}$ \\
\hline Structuring & $\begin{array}{l}\text { PLE is an invariant form for the development of a standard and/or individual } \\
\text { educational trajectory with the use of new technologies and approaches }\end{array}$ \\
\hline Functionality & $\begin{array}{l}\text { PLE is a person's set of actions (functions) in the course of educational activities which } \\
\text { involves the use of various means of communication, collective intelligence and a new } \\
\text { understanding of interactivity }\end{array}$ \\
\hline Organization & $\begin{array}{l}\text { PLE is diverse tool (options) for combining knowledge of basic, scientific and vocational } \\
\text { levels of education by creating a network of nodes from diverse sources of information: } \\
\text { people, organizations, libraries, sites, databases }\end{array}$ \\
\hline Procedures & $\begin{array}{l}\text { PLE is the technological tools (Web resources and services, algorithms, programs, and } \\
\text { models) used by a person in their learning process in order to find, interact with, } \\
\text { publish, organize, communicate and manage content }\end{array}$ \\
\hline Homeostasis & $\begin{array}{l}\text { PLE is the means of maintaining dynamic equilibrium and sustainability of the entity's } \\
\text { educational trajectory through international standards for the organization } \\
\text { of educational content and distance learning programs, } \\
\text { as well as the rules and practices of Web } 2.0 \text { \& Web } 3.0\end{array}$ \\
\hline Innovations & $\begin{array}{c}\text { PLE is a system of smart education that directs a person to be constantly ready to meet } \\
\text { the challenges of the changing world and comply with the requirements of the new, } \\
\text { progressive technological paradigm in the country }\end{array}$ \\
\hline
\end{tabular}

Figure. Personal learning environment as a complex system: definitions 
For the purpose of understanding the definition of PLE and the problems of its development in the society, we provide a structural etymological analysis and the results obtained in eight systemic contexts (representations), which are showin in Figure.

In a broad sense, PLE is an overly complex system, the purpose of which is to find suitable forms of organization for society in the face of contemporary world challenges and constant change, the development of educational strategies and technologies. Such a system is created by the entity itself, in accordance with its goals, and is implemented through the integration of different levels of knowledge through the development of an individual educational trajectory, and evolves along with personal and professional development of the individual.

\section{Conclusions and suggestions}

1. The system model can be seen as a tool for etymology, contributing to the development and improvement of the conceptual apparatus, the justification and rationalization of terminology structures, the formation of other new concepts. The results of the studies of specific terms and definitions show, first and foremost, the need to classify tax objects and systems. They can be conventionally divided into simple, complex and sophisticated systems. This determines the tools characteristic of a scientific theory (combination of theories) for its application in tax matters.

2. The emergence of the conceptual and categorical framework in the subject area which corresponds to the circumstances of the present day requires not only constant in-depth analysis of one or another word. We believe that it is equally important to include in this apparatus the interrelated terms characterizing the social phenomena that have a direct impact on the system under review.

3. In the field of taxation, the first step is to clarify the following concepts: techno-economic paradigm, technological paradigm, National Technology Initiative. Due to the fact that, tentatively, the Russian tax system should be classified as overly complex, Its study should be carried out in the context of the global development trends, the benchmarks outlined in the forecast of scientific and technological development up to 2030 and in other normative legal acts, in order to facilitate Russia's transition into the sixth progressive technological order.

\section{References}

1. Mayburov I. A., Ivanov Yu. B., Goncharenko L. I., Mironova O. A., Panskov V. G., Pinskaya M. R., Khanafeev F. F. et al. Entsiklopediya teoreticheskikh osnov nalogooblozheniya [Encyclopedia of theoretical bases of taxation]. Moscow, YUNITI-DANA Publ., 2016. 503 p.

2. Vylkova E. S., Mizgulin D. A. Upravlenie nalogooblozheniem v kommercheskikh bankakh: teoriya $i$ metodologiya [Taxation Management in Commercial Banks: Theory and Methodology]. St. Petersburg, Center for Training the Staff of the Russian Federal Tax Service Publ., 2012. $224 \mathrm{p}$.

3. Bryzgalin A. V., Bernik V. R., Golovkin A. N. Nalogovaya optimizatsiya: printsipy, metody, rekomendatsii, arbitrazhnaya praktika [Tax optimization: principles, methods, recommendations, arbitration practice]. $4^{\text {th }}$ ed. Moscow, Yurait-Izdat Publ., 2007. 320 p.

4. Tikhonov D. N., Lipnik L. G. Nalogovoe planirovanie i minimizatsiya nalogovykh riskov [Tax planning and minimization of tax risks]. Moscow, Alpina Business Books Publ., 2004. 253 p.

5. Armstrong C. S., Blouin J. L., Larcker D. F. The incentives for tax planning. Journal of Accounting and Economics, 2012, vol. 53, no. 1-2, pp. 391-411. DOI: 10.1016/j.jacceco.2011.04.001.

6. Su L. D., Zheng J. A study of the significance of tax planning for the enterprise's financial management. In Hsiang-Chuan Liu, Wen-Pei Sung, Wenli Yao (eds) Computing, Control, Information and Education Engineering. Proceedings of the $20152^{\text {nd }}$ International Conference on Computer, Intelligent and Education Technology (CICET 2015), April 11-12, 2015, Guilin, P.R. China. CRC Press, 2015, pp. 819-822.

7. Jalan A., Vaidyanathan R. Tax havens: conduits for corporate tax malfeasance. Journal of Financial Regulation and Compliance, 2017, vol. 25, no. 1, pp. 86-104. DOI: 10.1108/JFRC-042016-0039. 
8. Lipatova I. V., Polezharova L. V. International tax planning methodology and best practices of Russian economy deoffshorization. Asian Social Science, 2015, vol. 11, no. 19, pp. 316-328. DOI: $\underline{10.5539 / \text { ass.v11n19p316. }}$.

9. Poltorak A., Volosyuk Y. Tax risks estimation in the system of enterprises economic security. Economic Annals-XXI, 2016, vol. 158, no. 3-4, pp. 35-38. (In Ukrain.).

10. Chen B., Hong Q.-F., Zhang Y. Risk and prevention of tax planning. Xinan Shiyou Xueyuan Xuebao/Journal of Southwestern Petroleum Institute, 2005, vol. 27, no. 1, pp. 90-92.

11. Lavermicocca C., Buchan J. Role of reputational risk in tax decision making by large companies. eJournal of Tax Research, 2015, vol. 13, no. 1, pp. 5-50.

12. Sun P.-S., Fan Z.-P. A model of tax performance management based on knowledgesharing. Proceedings of the 2010 International Conference on Internet Technology and Applications. ITAP, 2010.

13. Sabrià-Bernadó B., Llinàs-Audet X., Isus S. Determinants of user demand for lifelong learning in institutions of higher education. International Journal of Training and Development, 2017, vol. 21, no. 2, pp. 145-166.

14. Rodríguez Terceño J., Gonzálvez Vallés J. E., Caldevilla Domínguez D. The environment of web 2.0 as a relational factor in the use of loyalty-raising parameters within the university environment. Advances in Intelligent Systems and Computing, 2017, vol. 503, pp. 449-454.

15. Alam S. L., Campbell J., Lucas R. Using social media in government: The Australian taxation office e-Tax facebook page. Proceedings of the 2011 IEEE 9th International Conference on Dependable, Autonomic and Secure Computing (DASC, 2011), December 12-14, 2011, Sydney, Australia. Institute of Electrical and Electronics Engineers, 2011, pp. 1002-1009.

16. Piñeiro Torres B., García González A. Evolution of the semantic web towards the intelligent web: From conceptualization to personalization of contents. Advances in Intelligent Systems and Computing, 2017, vol. 503, pp. 419-427.

17. Toporov V. N. Issledovaniya po etimologii i semantike. Tom 1. Teoriya i nekotorye chastnye ee prilozheniya [Studies in etymology and semantics. Vol. 1. Theory and some of its particular applications]. Moscow, Yazyki slavyanskoi kultury Publ., 2004. 816 p.

18. Viktorova N. G. Metodologiya i instrumenty upravleniya nalogooblozheniem i nalogovymi riskami na makro- i mikrourovnyakh. Dokt. Diss. [Methodology and tools for tax management and tax risks at macro and micro levels. Doct. Diss.]. St. Petersburg, 2015. 366 p.

19. Balatsky E. V. Vzaimosvyaz' ekonomiki i upravleniya: preodolenie kognitionogo razryva [Interrelation of Economics and Management: Overcoming the Cognitive Gap]. Available at: http:// kapital-rus.ru/articles/article/vzaimosvyaz_ekonomiki_i_upravleniya_preodolenie_kognitivnogo_razryva/ (In Russ.).

20. Viktorova N. G., Evstigneev E. N. Innovative approaches to the development of a professional management environment for technopark participants: the financial and tax aspect. Innovatsii = Innovations, 2016, no. 5, pp. 111-118. (In Russ.).

21. Evstigneev E. N. Term etymology "taxation management": system approach. Ekonomicheskii analiz: teoriya i praktika $=$ Economic Analysis: Theory and Practice, 2013, no. 47, pp. 47-55. (In Russ.).

22. Evstigneev E. N., Viktorova N. G. Problems of personnel, information and technological support of tax management: system approach. Journal of Tax Reform, 2015, no. 1, pp. 42-60. (In Russ.).

23. Ivanyan A. G., Che A. Yu. About tax risks. Nalogovyi vestnik, 2007, no. 10, pp. 3-7. (In Russ.).

24. Erezhnaya E. V., Porokhnya T. A., Kukota S. I. Analysis of existing risk definitions and approaches to its classification. Sbornik nauchnykh trudov SevKavGTU. Seriya "Ekonomika", 2005, no. 2, pp. 76-85. (In Russ.).

25. Pavlenko N. A. How to classify tax risks. Vash nalogovyi advokat, 2008, no. 12, pp. 13-15. Available at: https://www.lawmix.ru/bux/36277. (In Russ.).

26. Evstigneev E. N. Osnovy nalogovogo planirovaniya [Basics of tax planning]. St. Petersburg, Piter Publ., 2004. 288 p.

27. Kleiner G. B. A new theory of economic systems and its applications. Vestnik Rossiiskoi akademii nauk, 2011, vol. 81, no. 9, pp. 794-811. (In Russ.).

28. Dosi G. Technological paradigms and technological trajectories: a suggested interpretation of the determinants and directions of technical change. Research Policy, 1982, vol. 2, no. 3, pp. 147-162. DOI: 10.1016/0048-7333(82)90016-6. 
29. Perez C. Technological revolutions and techno-economic paradigms. Cambridge Journal of Economics, 2010, vol. 34, no. 1, pp. 185-202, DOI: 10.1093/cje/bep051.

30. Freeman C. The Economics of technical change. Cambridge Journal of Economics, 1994, vol. 18 , no. 5 , pp. $463-514$.

\section{Authors}

Evgeny N. Evstigneev - PhD in Economics, Professor, Peter the Great St. Petersburg Polytechnic University, Saint-Petersburg, Russia (29 Polytechnitcheskaya St., 195251, Saint-Petersburg, Russia); e-mail: eennn@mail.ru

Natalya G. Viktorova - Doctor of Economics, Associate Professor, Peter the Great St. Petersburg Polytechnic University, Saint-Petersburg, Russia (29 Polytechnitcheskaya St., 195251, Saint-Petersburg, Russia); e-mail: viknata@mail.ru

\section{Информация об авторах}

ЕВстигнееВ ЕВгений НиколаеВич - кандидат экономических наук, профессор, Высшая школа государственного и финансового управления Института промышленного менеджмента, экономики и торговли Санкт-Петербургского политехнического университета Петра Великого, г. Санкт-Петербург, Россия (195251, г. Санкт-Петербург, ул. Политехническая, 29); e-mail: eennn@mail.ru

Викторова Наталья Геннадьевна - доктор экономических наук, доцент, Высшая школа государственного и финансового управления Института промышленного менеджмента, экономики и торговли Санкт-Петербургского политехнического университета Петра Великого, г. Санкт-Петербург, Россия (195251, г. Санкт-Петербург, ул. Политехническая, 29); e-mail: viknata@mail.ru

\section{For citation}

Evstigneev E. N., Viktorova N. G. Etymology of Some Terms in the Tax Sphere: a Variant of System Perspective. Journal of Tax Reform, 2017, vol. 3, no. 2, pp. 78-91. DOI: $\underline{10.15826 / \text { jtr.2017.3.2.032 }}$

\section{Аия цитирования}

Евстигнеев Е. Н. Этимология некоторых терминов в сфере налогообложения: вариант системного подхода / Е. Н. Евстигнеев, Н. Г. Викторова // Journal of Tax Reform. - 2017. - T. 3, № 2. - C. 78-91. - DOI: $\underline{10.15826 / j t r .2017 .3 .2 .032}$

\section{Article info}

Received May 25, 2017; accepted July 1, 2017

\section{Информация о статье}

Дата поступления 25 мая 2017 г.; дата принятия к печати 1 июля 2017 г. 